\title{
Methodology to calculate the intensity of the electric field generated in a double circuit High Voltage Alternating Current overhead transmission line
}

\section{Metodología para calcular la intensidad del campo eléctrico generado en una línea de transmisión aérea de corriente alterna de alto voltaje de doble circuito}

\author{
AGUILAR-MARIN, Jorge Luis $\dagger^{* 1}$, VERGARA-VÁZQUEZ, Julio Cesar², PADILLA-CANTERO, \\ Jorge Gabriel ${ }^{3}$ and HERNÁNDEZ-GONZÁLEZ, Daniel ${ }^{4}$ \\ ${ }^{1}$ Universidad Autónoma del Estado de Morelos, Facultad de Ciencias Químicas e Ingeniería, Cuernavaca, México.
${ }^{2}$ Centro Nacional de Investigación y Desarrollo Tecnológico, Departamento de Ingeniería Mecánica, Cuernavaca, México.
${ }^{3}$ Instituto Nacional de Electricidad y Energías Limpias, Gerencia de Transmisión y Distribución, Cuernavaca, México.
${ }^{4}$ Tecnológico Nacional de México, Instituto Tecnológico de Toluca, Departamento de Metalmecánica, Metepec, México.
}

ID $1^{\text {st }}$ Author: Jorge Luis, Aguilar-Marin / ORC ID: 0000-0002-0235-6946, Researcher ID Thomson: ABD-4533-2020, CVU CONACYT ID: 1010823

ID $1^{\text {st }}$ Coauthor: Julio Cesar, Vergara-Vázquez / ORC ID: 0000-0003-1524-7914, Researcher ID Thomson: ABD-54872020

ID $2^{\text {nd }}$ Coauthor: Jorge Gabriel, Padilla-Cantero / ORC ID: 0000-0002-6414-9483, Researcher ID Thomson: ABD-53342020

ID $3^{\text {rd }}$ Coauthor: Daniel, Hernández-González / ORC ID: 0000-0002-9641-2717, Researcher ID Thomson: ABH-13892020

DOI: $10.35429 / J Q S A .2020 .21 .7 .1 .8$

Received October 14, 2020; Accepted December 29, 2020

\begin{abstract}
One of the parameters considered in the design of transmission lines is the distribution of its generated electric field. The following article presents a reference methodology that allows obtaining the electric field on the right-of-way of a High Voltage Alternating Current (HVAC) overhead transmission line, the methodology is developed based on the Load Simulation Method (MSC) and the Image Method. The results obtained present a difference of less than $2 \%$. In this way a case study of a $230 \mathrm{kV}$ HVAC double circuit transmission line presented, an optimization of the phases of the transmission line circuits is carried out to determine the most efficient configuration for obtaining the electric field density. The results obtained allow a configuration of $\mathrm{n}$ circuits, admitting the different nominal voltages of the HVAC lines.
\end{abstract}

Lines of transmission, Electric field strength, Phase of circuits, Electric field values

\begin{abstract}
Resumen
Uno de los parámetros considerados en el diseño de las líneas de transmisión es la distribución de su campo eléctrico generado. El siguiente artículo presenta una metodología de referencia que permite la obtención del campo eléctrico sobre el derecho de vía de una línea de transmisión aérea de Corriente Alterna de Alto Voltaje (HVAC), la metodología se desarrolla con base al Método de Simulación de Carga (MSC) y el Método de las imágenes. Los resultados obtenidos presentan una diferencia menor al $2 \%$. De esta manera se presenta un caso de estudio de una línea de transmisión de doble circuito de $230 \mathrm{kV}$ de HVAC, se realiza una optimización de las fases de los circuitos de la línea de transmisión, para determinar la configuración más eficiente para la obtención de la intensidad de campo eléctrico. Los resultados obtenidos permiten una configuración de $n$ circuitos, admitiendo las diferentes tensiones nominales de las líneas de HVAC.
\end{abstract}

Líneas de transmisión, Intensidad de campo eléctrico, Faseo de circuitos, Valores de campo eléctrico

Citation: AGUILAR-MARIN, Jorge Luis, VERGARA-VÁZQUEZ, Julio Cesar, PADILLA-CANTERO, Jorge Gabriel and HERNÁNDEZ-GONZÁLEZ, Daniel. Methodology to calculate the intensity of the electric field generated in a double circuit High Voltage Alternating Current overhead transmission line. Journal of Quantitative and Statistical Analysis. 2020. 7-21: 1-8

\footnotetext{
* Correspondence to Author (email: jorge.aguilar.itt@gmail.com)

$\dagger$ Researcher contributing as first author.
} 


\section{Introduction}

HVAC transmission lines are used to transmit large amounts of electrical power over long distances between electrical substations (Samy, Radwan \& Akef, 2017).

The length of the transmission line is a factor that impacts the parameters of the line and the associated losses (Ukil, 2015).

Another factor that affects the parameters for the design of HVAC transmission lines is the intensity of the electric field generated (Samy, Radwan \& Akef, 2017). The intensity of the electric field in overhead transmission lines is generated by the electric charge that circulates through the phase conductors, the field lines move away from the positive charges and towards the negative charges, Figure 1 shows their distribution (Grainger \& Stevenson, 1996).

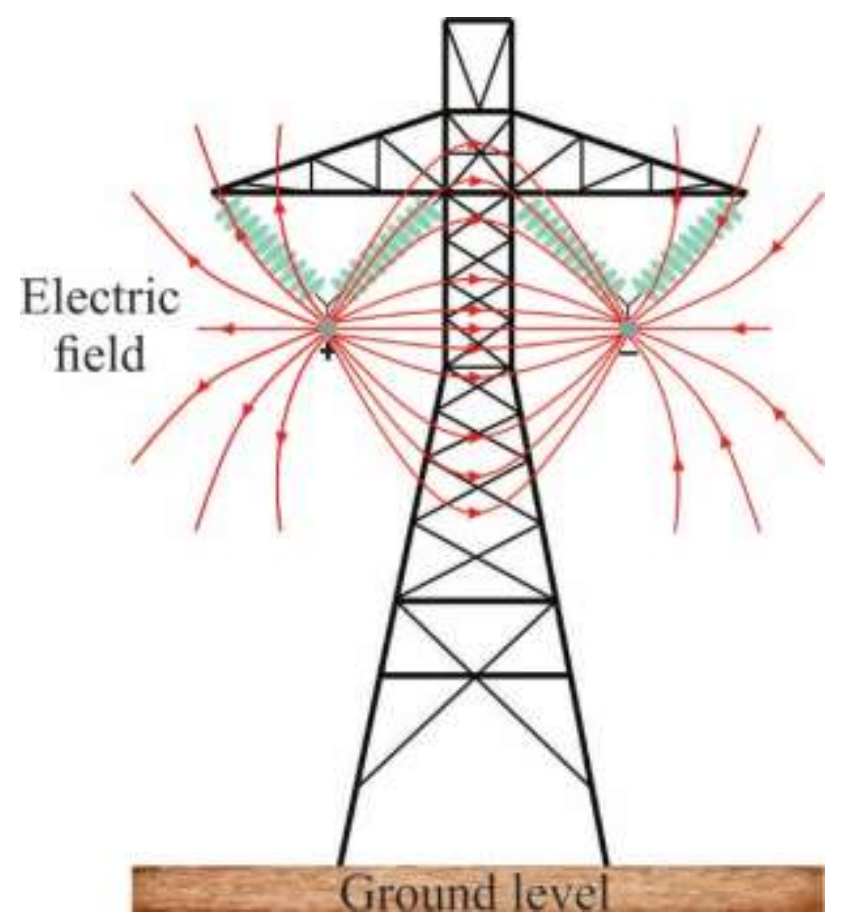

Figure 1 Electric field in an overhead transmission line Source: Own Elaboration

The heights of the conductors are designed to keep the discharge currents below the recommended exposure values for people immersed in this field and any equipment that may be found on the right of way of the transmission line (Duncan \& Malukutla, 2003), (Duncan \& Malukutla, 1993).

Some countries have adopted recommended limits on electric field intensity, they are presented in Table 1 (IEC, 2014).

\begin{tabular}{|c|r|}
\hline Country & \multicolumn{1}{c}{$\begin{array}{c}\text { Field value of phase to } \\
\text { neutral, in } \mathbf{~ k V / m}\end{array}$} \\
\hline USA & 30 \\
\hline Canada & 25 \\
\hline Brazil & 40 \\
\hline
\end{tabular}

Table 1 Electric field values at ground level Source: (IEC, 2014)

In accordance with (Sarma, 2000), an acceptable design should limit the electric field strength at ground level to $25 \mathrm{kV} / \mathrm{m}$. It should be noted that these limits are only established from the point of view of human perception.

To determine the intensity of electric fields, most of the cases require commercial software, among which PLS CADD, ETAP, DIGSilent, among others, stand out.

The present work provides a methodology that allows the calculation of the intensity of the electric field don the right of way of an overhead HVAC transmission line.

\section{Calculation methodology for electric field intensity}

The following methodology allows determining the components of the intensity of the electric field, at a point $(\mathrm{P})$ which is located on the right of way of a transmission line, given the location of the geometric coordinates $(x, y)$, this point will be under the effect of the load $\left(q_{k}\right)$ of the phase conductor located at the coordinates $\left(\mathrm{x}_{\mathrm{k}}, \mathrm{y}_{\mathrm{k}}\right)$. In the same way the point $(\mathrm{P})$ will be under the effect of negative charge $\left(-q_{k}\right)$ of the phase image conductor, located at the coordinates $\left(\mathrm{x}_{\mathrm{k}},-\mathrm{y}_{\mathrm{k}}\right)$ (Adel \& Dein, 2013).

The intensity of the electric field is calculated by means of the Charge Simulation Method (CSM), where the load $\left(q_{k}\right)$ is distributed on the surface of the phase conductor. The principle pf this methodology is presented in Figure 2 (Ortiz, 2007).

For the calculation, it is considered that there is no free charge in space and that the permittivity of air $\left(\varepsilon_{0}\right)$ is uniform and its conductivity is zero. In addition, the earth is considered a perfectly conductive surface where the effects of the image conductor are introduced (Adel \& Dein, 2013), (Ortiz, 2007). 


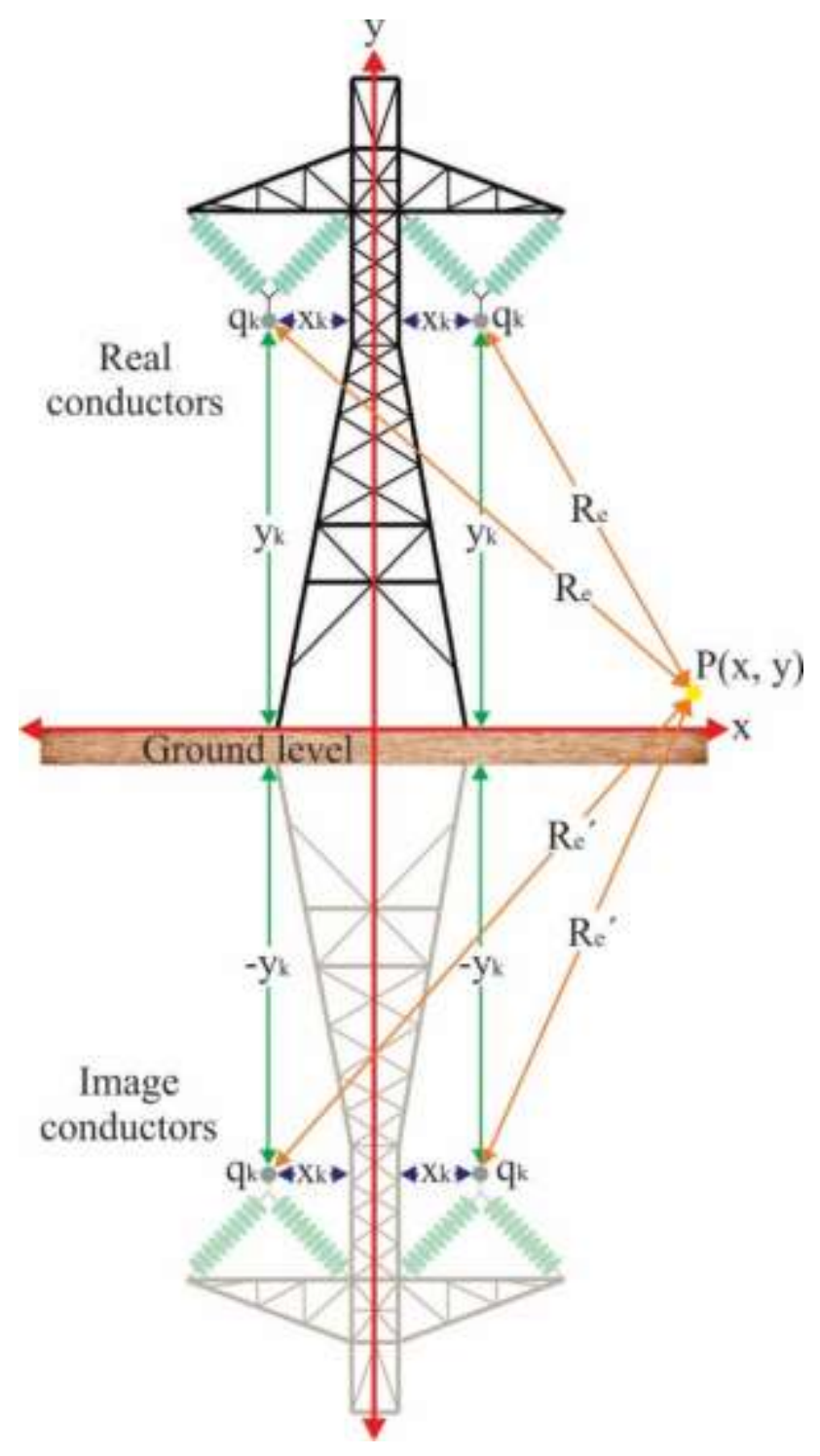

Figure 2 Geometric definition of variables.

Source: (Aguilar, Cisneros, Padilla \& Vergara, 2020)

Where:

$\mathrm{y}_{\mathrm{k}}=\quad$ Phase conductor height, in $\mathrm{m}$.

$\mathrm{x}_{\mathrm{k}}=$ Horizontal distance from the phase conductor to the reference $\mathrm{Y}$ axis, in $\mathrm{m}$.

$\mathrm{P}=\quad$ Point where you want to know the electric field intensity, in $\mathrm{m}$.

$\mathrm{R}_{\mathrm{e}}=$ Distance between the phase conductor and point $\mathrm{P}$, in $\mathrm{m}$.

$\mathrm{R}_{\mathrm{e}}{ }^{\prime}=$ Distance between the phase image conductor and point $\mathrm{P}$, in $\mathrm{m}$.

$\mathrm{q}_{\mathrm{k}}=$ Load of the phase conductors, in $\mathrm{C} / \mathrm{m}$.

$\mathrm{x}=$ Coordinate on the horizontal axis of point $\mathrm{P}$, in $\mathrm{m}$.

$y=\quad$ Coordinate on the vertical axis of point $\mathrm{P}$, in $\mathrm{m}$.

\section{Calculation of horizontal and vertical components}

Based on Figure 2, the equations of the horizontal and vertical components of the electric field intensity of the HVAC overhead transmission line are derived. However, prior to the calculation, the following considerations must be taken:

1. The phase to neutral voltages are part of a balanced tree phase system, out of phase $120^{\circ}$ electrical. A positive phase sequence is considered with phase $b$ as a reference.

2. The real and imaginary components of the charges are considered.

Using the above considerations, the contributions of the electric field intensity due to the effect of the charge in each of the components (horizontal and vertical) are obtained.

The horizontal and vertical components are obtained by means of equations (1) and (2) respectively (Lunca, Ursache \& Salceanu, 2017).

$\mathrm{E}_{\mathrm{x}_{\mathrm{k}}}=\sum_{\mathrm{k}=1}^{\mathrm{N}} \mathrm{E}_{\mathrm{C}}\left[\frac{\mathrm{x}-\mathrm{x}_{\mathrm{k}}}{\mathrm{R}_{\mathrm{e}}{ }^{2}}-\frac{\mathrm{x}-\mathrm{x}_{\mathrm{k}}}{\mathrm{R}_{\mathrm{e}}{ }^{2}}\right] \frac{\mathrm{V}}{\mathrm{m}}$

For the vertical components, equation (2) is used.

$E_{y_{k}}=-\sum_{k=1}^{N} E_{C}\left[\frac{y-y_{k}}{R_{e}{ }^{2}}-\frac{y+y_{k}}{R_{e}{ }^{2}}\right] \frac{v}{m}$

Where:

$\mathrm{E}_{\mathrm{x}_{\mathrm{k}}}=$ Horizontal component of electric field strength, in $\mathrm{V} / \mathrm{m}$.

$\mathrm{E}_{\mathrm{y}_{\mathrm{k}}}=$ Vertical component of electric field strength, in $\mathrm{V} / \mathrm{m}$.

$\mathrm{N}=$ Number of phases.

$E_{C}=$ Electric field effort at the surface of a conductor, in $\mathrm{V} / \mathrm{m}$.

The electric field effort on the surface of a phase conductor is obtained from equation (3) (Duncan \& Malukutla, 2003).

$\mathrm{E}_{\mathrm{C}}=\frac{\mathrm{q}_{\mathrm{k}}}{2 \pi \varepsilon_{0}} \frac{\mathrm{V}}{\mathrm{m}}$ 
Where:

$$
\begin{aligned}
\varepsilon_{0}=\quad & \text { Air permittivity }=8.854 \times 10^{-12}, \text { in } \\
& \mathrm{C}^{2} / \mathrm{N} \cdot \mathrm{m}^{2}
\end{aligned}
$$

The distance between the phase conductor and the measurement point $\mathrm{P}$, is obtained by the equation (4) (Carsimamovic, Mujezinovic, Bajramovic, Turkovic, Kosarac \& Stankovic, 2019).

$$
\mathrm{R}_{\mathrm{e}}=\sqrt{\left(\mathrm{x}-\mathrm{x}_{\mathrm{k}}\right)^{2}+\left(\mathrm{y}-\mathrm{y}_{\mathrm{k}}\right)^{2}} \mathrm{~m}
$$

The distance between the image phase conductor and the measurement point $\mathrm{P}$, is obtained by the equation (5) (Carsimamovic, Mujezinovic, Bajramovic, Turkovic, Kosarac \& Stankovic, 2019).

$$
\mathrm{R}_{\mathrm{e}}{ }^{\prime}=\sqrt{\left(\mathrm{x}-\mathrm{x}_{\mathrm{k}}\right)^{2}+\left(\mathrm{y}+\mathrm{y}_{\mathrm{k}}\right)^{2}} \mathrm{~m}
$$

\section{Calculation of electric field strength}

The total electric field intensity at the measurement point $\mathrm{P}$ is obtained by applying equation (6).

$\mathrm{E}_{\mathrm{T}}=\sqrt{\mathrm{E}_{\mathrm{x}_{\mathrm{k}}}^{2}+\mathrm{E}_{\mathrm{y}_{\mathrm{k}}}^{2}} \frac{\mathrm{kV}}{\mathrm{m}}$

Where:

$E_{T}=$ Total magnitude of the electric field intensity at the measurement point $\mathrm{P}$, in $\mathrm{kV} / \mathrm{m}$.

IEEE recommends that the electric field calculation be considered at $1 \mathrm{~m}$ above ground level (IEEE, 2002).

\section{Case study}

It is considered a $230 \mathrm{kV}$ double circuit HVAC transmission line where you want to determine the intensity of the electric field at one meter above ground level, on a right of way of $80 \mathrm{~m}$. Figure 3 shows the configuration of the transmission tower, the separation between the phases and their location above ground level. Table 2 shows the spatial coordinates of the phase conductor locations for the C-1 configuration. Table 3 shows the transmission line loads.

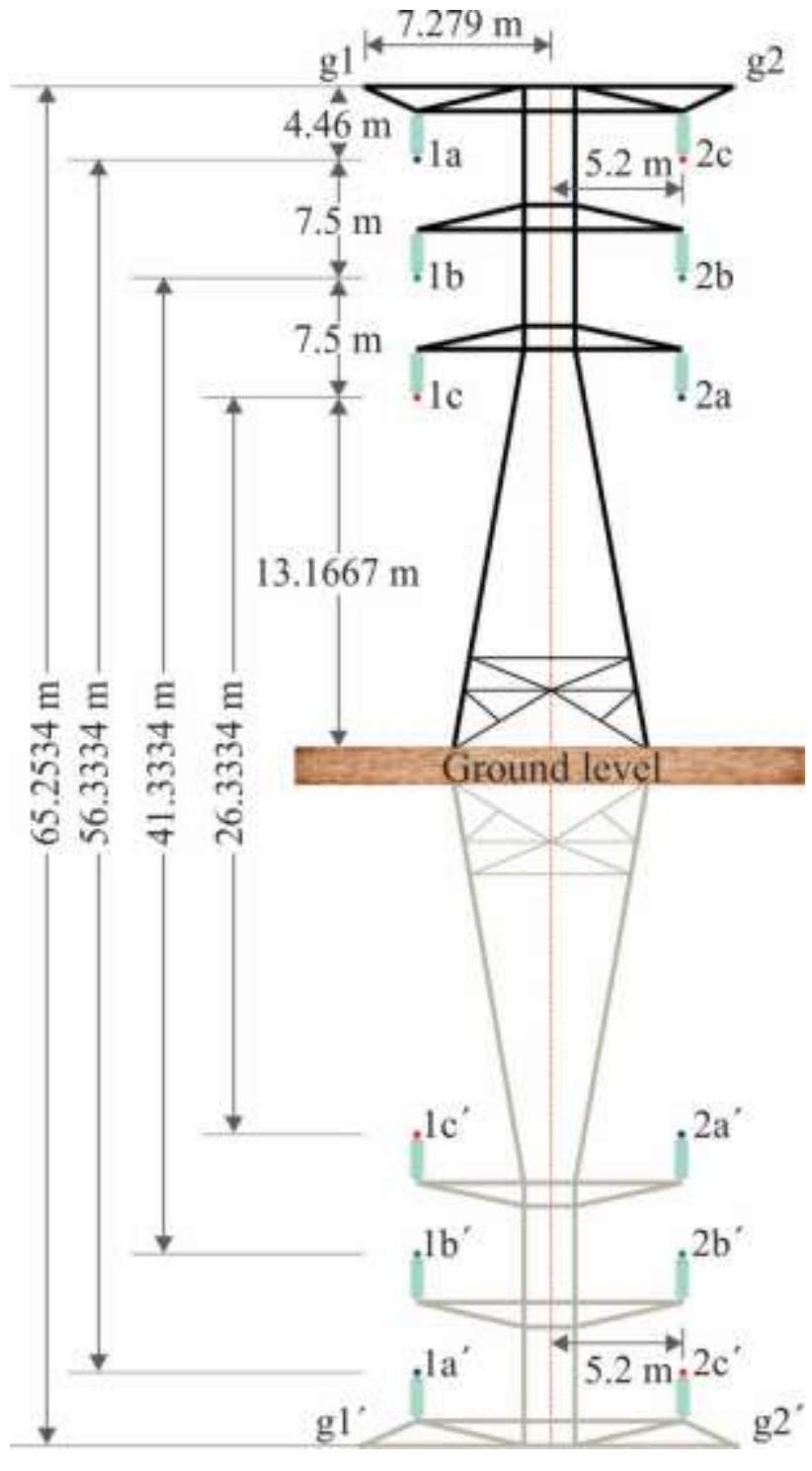

Figure 3 Profile of $230 \mathrm{kV}$ HVAC double circuit transmission line

Source: Own elaboration

\begin{tabular}{|c|c|c|}
\hline Phase & $\mathbf{x}_{\mathbf{k}}$ & $\mathbf{y}_{\mathbf{k}}$ \\
\hline $1 \mathrm{a}$ & $-5.2 \mathrm{~m}$ & $28.1667 \mathrm{~m}$ \\
\hline $1 \mathrm{~b}$ & $-5.2 \mathrm{~m}$ & $20.6667 \mathrm{~m}$ \\
\hline $1 \mathrm{c}$ & $-5.2 \mathrm{~m}$ & $13.1667 \mathrm{~m}$ \\
\hline $2 \mathrm{a}$ & $5.2 \mathrm{~m}$ & $13.1667 \mathrm{~m}$ \\
\hline 2b & $5.2 \mathrm{~m}$ & $20.6667 \mathrm{~m}$ \\
\hline 2c & $5.2 \mathrm{~m}$ & $28.1667 \mathrm{~m}$ \\
\hline
\end{tabular}

Table 2 Spatial coordinates of the C-1 phase conductors of the double circuit transmission line Source: Own elaboration 


\begin{tabular}{|c|c|c|}
\hline \multirow{2}{*}{$\begin{array}{l}\text { Phase } \\
\text { loading }\end{array}$} & \multicolumn{2}{|c|}{ Load in each phase, in $\mathrm{C} / \mathrm{m}$} \\
\hline & $\begin{array}{l}\text { Polar } \\
\text { shape }\end{array}$ & $\begin{array}{l}\text { Rectangular } \\
\text { shape }\end{array}$ \\
\hline $\mathrm{q}_{1 \mathrm{a}}$ & $\begin{array}{c}-661.801 \times 10^{-9} \\
+1.033 \times 10^{-6} \mathrm{j}\end{array}$ & $\begin{array}{l}1.226 \times 10^{-6} \\
\angle 122.646\end{array}$ \\
\hline $\mathrm{q}_{1 \mathrm{~b}}$ & $\begin{array}{r}1.193 \times 10^{-6} \\
+1.142 \times 10^{-9} \mathrm{j} \\
\end{array}$ & $\begin{array}{c}1.193 \times 10^{-6} \\
\angle 0.054\end{array}$ \\
\hline $\mathrm{q}_{1 \mathrm{c}}$ & $\begin{array}{l}-660.341 \times 10^{-9} \\
-1.023 \times 10^{-6} \mathrm{j} \\
\end{array}$ & $\begin{array}{l}1.217 \times 10^{-6} \\
\angle-122.842 \\
\end{array}$ \\
\hline $\mathrm{q}_{2 \mathrm{a}}$ & $\begin{array}{l}-660.341 \times 10^{-9} \\
+1.023 \times 10^{-6} \mathrm{j} \\
\end{array}$ & $\begin{array}{c}1.217 \times 10^{-6} \\
\angle 122.842 \\
\end{array}$ \\
\hline $\mathrm{q}_{2 \mathrm{~b}}$ & $\begin{array}{c}1.193 \times 10^{-6} \\
-1.142 \times 10^{-9} \mathrm{j} \\
\end{array}$ & $\begin{array}{c}1.193 \times 10^{-6} \\
\angle-0.054\end{array}$ \\
\hline $\mathrm{q}_{2 \mathrm{c}}$ & $\begin{array}{l}-661.801 \times 10^{-9} \\
-1.033 \times 10^{-6} \mathrm{j} \\
\end{array}$ & $\begin{array}{l}1.226 \times 10^{-6} \\
\angle-122.646 \\
\end{array}$ \\
\hline
\end{tabular}

Table 3 Double circuit transmission line loads Source: Own elaboration

\section{Calculation of horizontal and vertical components}

The calculation of the electric field effort is determined by means of equation (3).

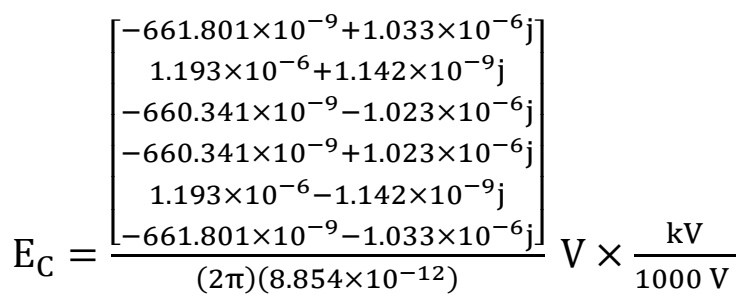$$
\mathrm{E}_{\mathrm{C}}=\left[\begin{array}{c}
-11.8961+18.5686 \mathrm{j} \\
21.4447+0.0205 \mathrm{j} \\
-11.8699-18.3889 \mathrm{j} \\
-11.8699+18.3889 \mathrm{j} \\
21.4447-0.0205 \mathrm{j} \\
-11.8961-18.5686 \mathrm{j}
\end{array}\right] \mathrm{kV}
$$

The distance from the phase conductor to the measurement point $\mathrm{P}$ is obtained, applying equation (4).

Distance from phase 1a, considering a point $P(x=0, y=1)$.

$$
\begin{aligned}
& \mathrm{R}_{\mathrm{e} 1 \mathrm{a}}=\sqrt{(0-(-5.2))^{2}+(1-28.167)^{2}} \mathrm{~m} \\
& \mathrm{R}_{\mathrm{e} 1 \mathrm{a}}=27.66 \mathrm{~m}
\end{aligned}
$$

The distance from the phase conductor to the measurement point $\mathrm{P}(\mathrm{x}=0, \mathrm{y}=1)$, is obtained by applying equation (5).

$$
\begin{aligned}
\mathrm{R}_{\mathrm{e}^{\prime} 1 \mathrm{a}} & =\sqrt{(0-(-5.2))^{2}+(1+28.167)^{2}} \mathrm{~m} \\
\mathrm{R}_{\mathrm{e}}^{\prime} 1 \mathrm{a} & =29.62 \mathrm{~m}
\end{aligned}
$$

For the rest of the phase conductors and phase image conductors at point $\mathrm{P}(\mathrm{x}=0, \mathrm{y}=1)$ the results shown in Table 4.

\begin{tabular}{|c|c|}
\hline \multicolumn{2}{|c|}{ Distance $\mathrm{R}_{\mathrm{e}}$ Distance $\mathrm{R}_{\mathrm{e}}^{\prime}$} \\
\hline $\mathrm{R}_{\mathrm{e} 1 \mathrm{~b}}=20.34 \mathrm{~m}$ & $\mathrm{R}_{\mathrm{e}^{\prime} 1 \mathrm{~b}}=22.28 \mathrm{~m}$ \\
\hline $\mathrm{R}_{\mathrm{e} 1 \mathrm{c}}=13.23 \mathrm{~m}$ & $\mathrm{R}_{\mathrm{e}_{1 \mathrm{c}}^{\prime}}=15.09 \mathrm{~m}$ \\
\hline $\mathrm{R}_{\mathrm{e} 2 \mathrm{a}}=13.23 \mathrm{~m}$ & $\mathrm{R}_{\mathrm{e}^{\prime} 2 \mathrm{a}}=15.09 \mathrm{~m}$ \\
\hline $\mathrm{R}_{\mathrm{e} 2 \mathrm{~b}}=20.34 \mathrm{~m}$ & $\mathrm{R}_{\mathrm{e}^{\prime} 2 \mathrm{~b}}=22.28 \mathrm{~m}$ \\
\hline $\mathrm{R}_{\mathrm{e} 2 \mathrm{c}}=27.66 \mathrm{~m}$ & $\mathrm{R}_{\mathrm{e}^{\prime} 2 \mathrm{c}}=29.62 \mathrm{~m}$ \\
\hline
\end{tabular}

Table 4 Distances $R_{e} y R_{e}{ }^{\prime}$ to point $P(x=0, y=1)$

The calculation of the horizontal components of the electric field is performed using equation (1), for $\mathrm{P}(\mathrm{x}=0, \mathrm{y}=1)$.

$$
\begin{aligned}
& \mathbf{E x}_{\mathbf{0}}=\left(E_{\mathrm{C} 1 \mathrm{a}}\right)\left[\frac{\mathrm{x}-\mathrm{x}_{\mathrm{k} 1 \mathrm{a}}}{\left(\mathrm{R}_{\mathrm{e} 1 \mathrm{a}}\right)^{2}}-\frac{\mathrm{x}-\mathrm{x}_{\mathrm{k} 1 \mathrm{a}}}{\left(\mathrm{R}_{\mathrm{e} 1 \mathrm{a}}^{\prime}\right)^{2}}\right] \\
& +\left(E_{\mathrm{C} 1 \mathrm{~b}}\right)\left[\frac{\mathrm{x}-\mathrm{x}_{\mathrm{k} 1 \mathrm{~b}}}{\left(\mathrm{R}_{\mathrm{e} 1 \mathrm{~b}}\right)^{2}}-\frac{\mathrm{x}-\mathrm{x}_{\mathrm{k} 1 \mathrm{~b}}}{\left(\mathrm{R}_{\mathrm{e}}{ }^{\prime} 1 \mathrm{~b}\right)^{2}}\right]
\end{aligned}
$$

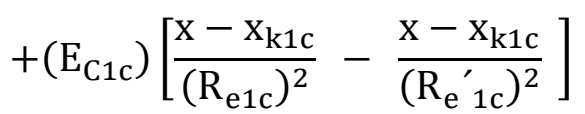

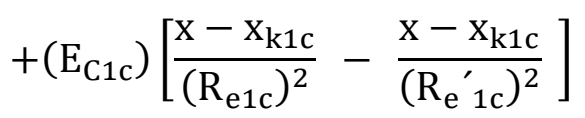

$$
\begin{aligned}
& +\left(E_{\mathrm{C} 2 \mathrm{a}}\right)\left[\frac{\mathrm{x}-\mathrm{x}_{\mathrm{k} 2 \mathrm{a}}}{\left(\mathrm{R}_{\mathrm{e} 2 \mathrm{a}}\right)^{2}}-\frac{\mathrm{x}-\mathrm{x}_{\mathrm{k} 2 \mathrm{a}}}{\left(\mathrm{R}_{\mathrm{e} 2 \mathrm{a}}\right)^{2}}\right] \\
& +\left(E_{\mathrm{C} 2 \mathrm{~b}}\right)\left[\frac{\mathrm{x}-\mathrm{x}_{\mathrm{k} 2 \mathrm{~b}}}{\left(\mathrm{R}_{\mathrm{e} 2 \mathrm{~b}}\right)^{2}}-\frac{\mathrm{x}-\mathrm{x}_{\mathrm{k} 2 \mathrm{~b}}}{\left(\mathrm{R}_{\mathrm{e} 2 \mathrm{~b}}\right)^{2}}\right] \\
& +\left(E_{C 2 c}\right)\left[\frac{x-x_{k 2 c}}{\left(R_{e 2 c}\right)^{2}}-\frac{x-x_{k 2 c}}{\left(R_{e}{ }^{\prime} c\right)^{2}}\right] \frac{k V}{m} \\
& \mathbf{E x}_{\mathbf{0}}=0.00008-0.2203 \mathrm{j} \frac{\mathrm{kV}}{\mathrm{m}} \\
& \mathbf{E x}_{\mathbf{0}}=\sqrt{(0.00008)^{2}+(-0.2203 \mathrm{j})^{2}} \frac{\mathrm{kV}}{\mathrm{m}} \\
& \mathbf{E x}_{\mathbf{0}}=0.2203 \frac{\mathrm{kV}}{\mathrm{m}}
\end{aligned}
$$

The calculation of the vertical components of the electric field is performed using equation (2), for $\mathrm{P}(\mathrm{x}=0, \mathrm{y}=1)$.

$$
\begin{aligned}
& \mathbf{E y}_{0}=-1\left[\left(E_{\mathrm{C} 1 \mathrm{a}}\right)\left[\frac{\mathrm{y}-\mathrm{y}_{\mathrm{k} 1 \mathrm{a}}}{\left(\mathrm{R}_{\mathrm{e} 1 \mathrm{a}}\right)^{2}}-\frac{\mathrm{y}-\mathrm{y}_{\mathrm{k} 1 \mathrm{a}}}{\left(\mathrm{R}_{\mathrm{e} 1 \mathrm{a}}^{\prime}\right)^{2}}\right]\right. \\
& +\left(E_{\mathrm{C} 1 \mathrm{~b}}\right)\left[\frac{\mathrm{y}-\mathrm{y}_{\mathrm{k} 1 \mathrm{~b}}}{\left(\mathrm{R}_{\mathrm{e} 1 \mathrm{~b}}\right)^{2}}-\frac{\mathrm{y}-\mathrm{y}_{\mathrm{k} 1 \mathrm{~b}}}{\left(\mathrm{R}_{\mathrm{e} 1 \mathrm{~b}}^{\prime}\right)^{2}}\right] \\
& +\left(E_{\mathrm{C} 1 \mathrm{c}}\right)\left[\frac{\mathrm{y}-\mathrm{y}_{\mathrm{k} 1 \mathrm{c}}}{\left(\mathrm{R}_{\mathrm{e} 1 \mathrm{c}}\right)^{2}}-\frac{\mathrm{y}-\mathrm{y}_{\mathrm{k} 1 \mathrm{c}}}{\left(\mathrm{R}_{\mathrm{e} 1 \mathrm{c}}^{\prime}\right)^{2}}\right] \\
& +\left(E_{\mathrm{C} 1 \mathrm{c}}\right)\left[\frac{\mathrm{y}-\mathrm{x}_{\mathrm{k} 1 \mathrm{c}}}{\left(\mathrm{R}_{\mathrm{e} 1 \mathrm{c}}\right)^{2}}-\frac{\mathrm{y}-\mathrm{y}_{\mathrm{k} 1 \mathrm{c}}}{\left(\mathrm{R}_{\mathrm{e} 1 \mathrm{c}}^{\prime}\right)^{2}}\right]
\end{aligned}
$$

AGUILAR-MARIN, Jorge Luis, VERGARA-VÁZQUEZ, Julio Cesar, PADILLA-CANTERO, Jorge Gabriel and HERNÁNDEZ-GONZÁLEZ, Daniel. Methodology to calculate the intensity of the electric field generated in a double circuit High Voltage Alternating Current overhead transmission line. Journal of Quantitative and Statistical Analysis. 2020 


$$
\begin{aligned}
& +\left(E_{C 2 a}\right)\left[\frac{y-y_{k 2 a}}{\left(R_{e 2 a}\right)^{2}}-\frac{y-y_{k 2 a}}{\left(R_{e}{ }^{\prime} a\right)^{2}}\right] \\
& +\left(E_{C 2 b}\right)\left[\frac{y-y_{k 2 b}}{\left(R_{e 2 b}\right)^{2}}-\frac{y-y_{k 2 b}}{\left(R_{e}^{\prime} 2 b\right)^{2}}\right] \\
& \left.+\left(E_{\mathrm{C} 2 \mathrm{c}}\right)\left[\frac{\mathrm{y}-\mathrm{y}_{\mathrm{k} 2 \mathrm{c}}}{\left(\mathrm{R}_{\mathrm{e} 2 \mathrm{c}}\right)^{2}}-\frac{\mathrm{y}-\mathrm{y}_{\mathrm{k} 2 \mathrm{c}}}{\left(\mathrm{R}_{\mathrm{e} 2 \mathrm{c}}\right)^{2}}\right]\right] \frac{\mathrm{kV}}{\mathrm{m}} \\
& \mathbf{E y}_{\mathbf{0}}=-0.8536+0 \mathrm{j} \frac{\mathrm{kV}}{\mathrm{m}} \\
& \mathbf{E y}_{\mathbf{0}}=\sqrt{(-0.8536)^{2}+(0 \mathrm{j})^{2}} \frac{\mathrm{kV}}{\mathrm{m}} \\
& \mathbf{E y}_{\mathbf{0}}=0.8536 \frac{\mathrm{kV}}{\mathrm{m}}
\end{aligned}
$$

\section{Calculation of electric field strength}

Finally, the total intensity of the electric field is calculated at the measurement point $\mathrm{P}(\mathrm{x}=0, \mathrm{y}=$ $1)$, using equation (6).

$$
\begin{aligned}
& \mathrm{E}_{\mathrm{T} 0}=\sqrt{(0.2203)^{2}+(0.8536)^{2}} \frac{\mathrm{kV}}{\mathrm{m}} \\
& \mathrm{E}_{\mathrm{T} 0}=0.8815 \frac{\mathrm{kV}}{\mathrm{m}}
\end{aligned}
$$

Table 5 shows the results obtained from the total intensity of the electric field on the right of way, using intervals of $10 \mathrm{~m}$ of the right of way.

\begin{tabular}{|c|l|}
\hline \multicolumn{1}{c|}{ Coordinates } & Electric field intensity, in $\mathbf{~ V V / m}$ \\
\hline $\mathrm{P}(\mathrm{x}=0, \mathrm{y}=1)$ & $\mathrm{E}_{\mathrm{T} 0}=0.8815$ \\
\hline $\mathrm{P}(\mathrm{x}=10, \mathrm{y}=1)$ & $\mathrm{E}_{\mathrm{T} 10}=1.1475$ \\
\hline $\mathrm{P}(\mathrm{x}=20, \mathrm{y}=1)$ & $\mathrm{E}_{\mathrm{T} 20}=0.3070$ \\
\hline $\mathrm{P}(\mathrm{x}=30, \mathrm{y}=1)$ & $\mathrm{E}_{\mathrm{T} 30}=0.0610$ \\
\hline $\mathrm{P}(\mathrm{x}=40, \mathrm{y}=1)$ & $\mathrm{E}_{\mathrm{T} 40}=0.0406$ \\
\hline
\end{tabular}

Table 5 Electric field intensity on the right of way of the transmission line

In Figure 4, the plotted results of the electric field intensity on the right of way of the $230 \mathrm{kV}$ double circuit transmission line.

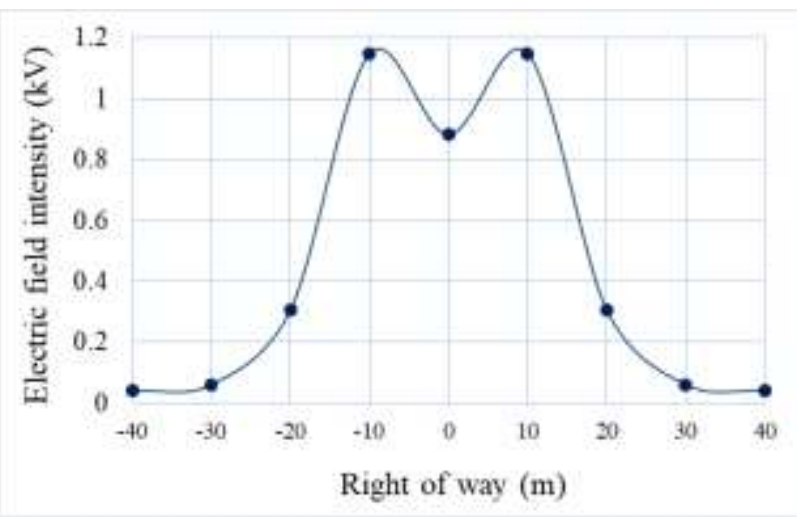

Figure 4 Electric field intensity of C-1 from transmission line
Figure 4 shows that for the transmission line under study, the maximum electric field intensity is $1.1475 \mathrm{kV} / \mathrm{m}$, which is lower than the maximum limit recommended by (Sarma, 2000).

\section{Results}

To obtain a validation of the methodology presented to calculate the intensity of the electric field, a simulation of the transmission line under study is carried out, for this the FACE software was used (FACE, 2019).

Table 6 and Figure 5 show the comparison of the results obtained between the methodology presented and the validation of the FACE software.

\begin{tabular}{|l|l|}
\hline \multicolumn{2}{|c|}{ Electric field strength } \\
Methodology, in kV & \multicolumn{1}{|c|}{ FACE, in kV } \\
\hline $\mathrm{E}_{\mathrm{T} 0}=0.8815$ & $\mathrm{E}_{\mathrm{T} 0}=0.8815$ \\
\hline $\mathrm{E}_{\mathrm{T} 10}=1.1475$ & $\mathrm{E}_{\mathrm{T} 10}=1.1475$ \\
\hline $\mathrm{E}_{\mathrm{T} 20}=0.3070$ & $\mathrm{E}_{\mathrm{T} 20}=0.3070$ \\
\hline $\mathrm{E}_{\mathrm{T} 30}=0.0610$ & $\mathrm{E}_{\mathrm{T} 30}=0.0610$ \\
\hline $\mathrm{E}_{\mathrm{T} 40}=0.0406$ & $\mathrm{E}_{\mathrm{T} 40}=0.0406$ \\
\hline
\end{tabular}

Table 6 Comparison of the results obtained between the methodology and the FACE software

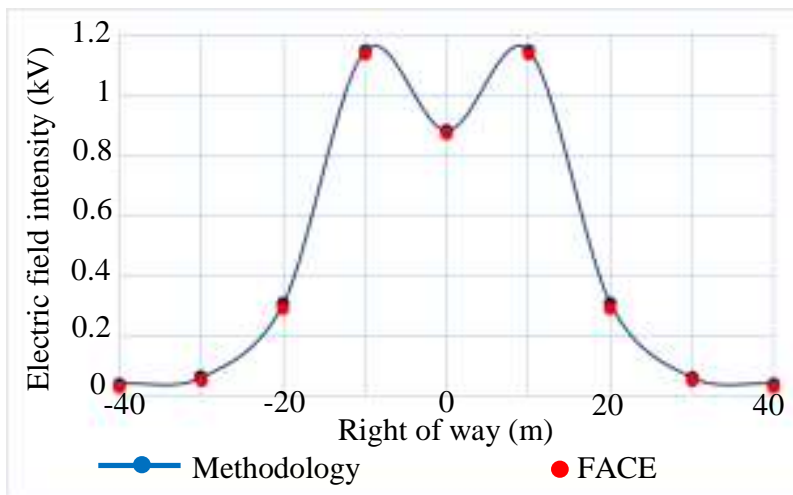

Figure 5 Comparison of the results obtained between the methodology and the FACE software

Comparing the results, a percentage difference of $2 \%$ is present between the methodology and the FACE software.

\section{Optimization of the phases of the circuits in the electric field intensity}

For the optimization of the phases in the transmission line, 2 configurations are considered (C-2 and C-3), which are presented in Tables 7 and 8 respectively. This will allow to evaluate the behavior of the electric field intensity.

AGUILAR-MARIN, Jorge Luis, VERGARA-VÁZQUEZ, Julio Cesar, PADILLA-CANTERO, Jorge Gabriel and HERNÁNDEZ-GONZÁLEZ, Daniel. Methodology to calculate the intensity of the electric field generated in a double circuit High Voltage Alternating Current overhead transmission line. Journal of Quantitative and Statistical Analysis. 2020 
Table 7 shows the coordinates of the C-2 phase conductors of the transmission line.

\begin{tabular}{|c|c|c|}
\hline Phase & \multicolumn{1}{c|}{$\mathbf{x}_{\mathbf{k}}$} & $\mathbf{y}_{\mathbf{k}}$ \\
\hline $1 \mathrm{a}$ & $-5.2 \mathrm{~m}$ & $28.1667 \mathrm{~m}$ \\
\hline $1 \mathrm{~b}$ & $-5.2 \mathrm{~m}$ & $20.6667 \mathrm{~m}$ \\
\hline $1 \mathrm{c}$ & $-5.2 \mathrm{~m}$ & $13.1667 \mathrm{~m}$ \\
\hline $2 \mathrm{c}$ & $5.2 \mathrm{~m}$ & $28.1667 \mathrm{~m}$ \\
\hline $2 \mathrm{~b}$ & $5.2 \mathrm{~m}$ & $20.6667 \mathrm{~m}$ \\
\hline $2 \mathrm{a}$ & $5.2 \mathrm{~m}$ & $13.1667 \mathrm{~m}$ \\
\hline
\end{tabular}

Table 7 Coordinates of the phase conductors of C-2 of the transmission line

Performing the procedure of the methodology with configuration presented in Table 7, the results of the electric field intensity on the right of way shown in Figure 6 are obtained.

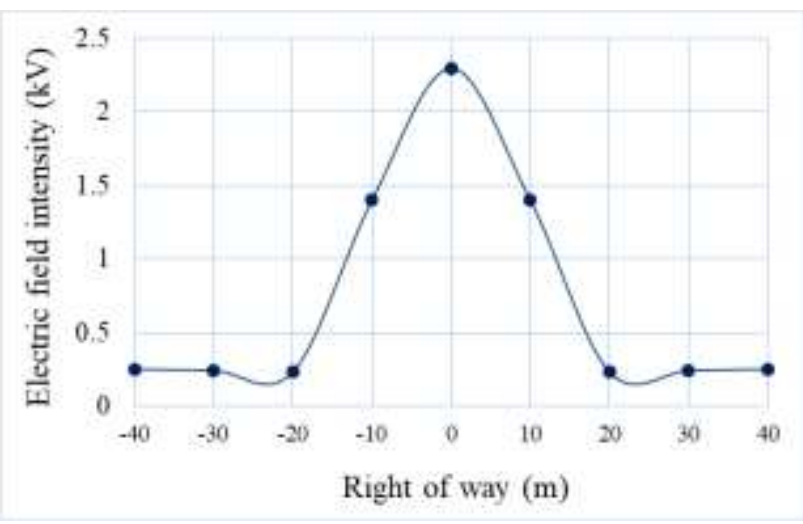

Figure 6 Electric field intensity of C-2 from HVAC 230 $\mathrm{kV}$ double circuit transmission line

Table 8 shows the coordinated of the C-3 phase conductors of the transmission line.

\begin{tabular}{|c|c|c|}
\hline Phase & $\mathbf{x}_{\mathbf{k}}$ & $\mathbf{y}_{\mathbf{k}}$ \\
\hline $1 \mathrm{c}$ & $-5.2 \mathrm{~m}$ & $13.1667 \mathrm{~m}$ \\
\hline $1 \mathrm{a}$ & $-5.2 \mathrm{~m}$ & $28.1667 \mathrm{~m}$ \\
\hline $1 \mathrm{~b}$ & $-5.2 \mathrm{~m}$ & $20.6667 \mathrm{~m}$ \\
\hline $2 \mathrm{a}$ & $5.2 \mathrm{~m}$ & $13.1667 \mathrm{~m}$ \\
\hline $2 \mathrm{~b}$ & $5.2 \mathrm{~m}$ & $20.6667 \mathrm{~m}$ \\
\hline $2 \mathrm{c}$ & $5.2 \mathrm{~m}$ & $28.1667 \mathrm{~m}$ \\
\hline
\end{tabular}

Table 8 Coordinates of the phase conductors of C-3 of the transmission line

Carry out the previous procedure with the configuration shown in Table 8 , the results of the electric field intensity on the right of way shown in Figure 7 are obtained.

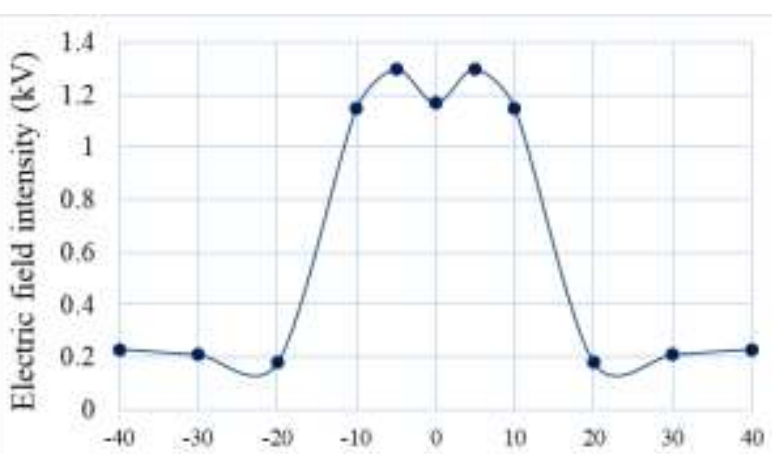

Right of way (m)

Figure 7 Electric field intensity of C-3 from HVAC 230 $\mathrm{kV}$ double circuit transmission line

Based on the results obtained, a better behavior of the electric field intensity is observed considering the $\mathrm{C}-1$ configuration, with a better performance of $11.73 \%$ compared to $\mathrm{C}-2$ and $50.53 \%$ compared to $\mathrm{C}-3$.

\section{Conclusions}

The following points are concluded from the article made:

- A reference methodology is presented, which contains the necessary steps to perform the calculation of the electric field intensity on the right of way of HVAC overhead transmission lines.

- The methodology presented may be applied in transmission lines of 1 to $n$ circuits, admitting the different nominal voltages of the HVAC lines.

- By optimizing the phases of the transmission line circuits, the most efficient configuration for obtaining the electric field intensity is determined.

- The electric field intensity profile of the $230 \mathrm{kV}$ HVAC double circuit transmission line was validated with the FACE software, with which a difference of $2 \%$ is obtained.

- In future works, the methodology presented may be applied avoiding the use of commercial programs, since this methodology has been successfully validated.

\section{References}

Adel, Z. \& Dein, E. (2013). Effect of the variation pf the charge distribution along multioverhead transmission lines' conductors on the calculation method of ground surface electric field.

AGUILAR-MARIN, Jorge Luis, VERGARA-VÁZQUEZ, Julio Cesar, PADILLA-CANTERO, Jorge Gabriel and HERNÁNDEZ-GONZÁLEZ, Daniel. Methodology to calculate the intensity of the electric field generated in a double circuit High Voltage Alternating Current overhead transmission line. Journal of Quantitative and Statistical Analysis. 2020 
Aguilar, J. Cisneros, L. Padilla, J \& Vergara, J. (2020). Methodology to calculate the density of the magnetic field generated in overhead transmission lines in HVDC applying a twodimensional analysis of parallel poles above ground level. Journal - Democratic Republic of Congo.

Carsimamovic, A. Mujezinovic, A. Bajramovic, Z. Turkovic, I. Kosarac, M. \& Stankovic, K. (2019). Origin and mitigation of increased electric fields at high voltage transmission line conductors.

Duncan, J. \& Malukutla, S. (2003). Sistemas de potencia.

Duncan, J. \& Malukutla, S. (1993). Power system analysis.

FACE. (2019). Field and corona effects, Manitoba hydro international. Canada.

Grainger, J. \& Stevenson, W. (1996). Análisis de sistemas eléctricos de potencia.

IEEE. (2002). IEEE STD C95.6 Safety levels with respect to human exposure to electromagnetic fields, $0-3 \mathrm{kHz}$.

IEC. (2014). IEC 62681 Electromagnetic performance of high voltage direct current (HVDC) overhead transmission lines.

Lunca, E. Ursache, S. \& Salceanu, A. (2017). Computation and Analysis of the Extremely Low Frequency Electric and Magnetic Fields Generated by Tow Designs of $400 \mathrm{kV}$ Overhead Transmission Lines.

Ortiz, L. (2007). Estudio de campos eléctricos y magnéticos de la línea de transmisión de $220 \mathrm{kV}$, Pan de Azúcar-Andacollo. Santiago de Chile.

Samy, M. Radwan, R. \& Akef, S. (2017). Calculation of electric fields underneath and on conductor surfaces of ultra high voltage transmission lines.

Sarma, Maruvada, P. (2000). Corona performance of high-voltage transmission lines. Canada.

Ukil, A. (2015). Theoretical analysis of tuned HVAC line for low loss long distance bulk power transmission. 